\title{
Clinical Reasoning: A 70-Year-Old Man With Right Arm and Leg Shaking
}

Jessica Frey, MD, and Eric Seachrist, MD

Neurology ${ }^{\circledR} 2021 ; 96: 1098-1101$. doi:10.1212/WNL.0000000000012047
Correspondence

Dr. Frey

jess.el.frey@gmail.com

\section{Section 1}

A 70-year-old man with a medical history significant for abdominal aortic aneurysm and provoked deep vein thrombus (DVT) (no longer on anticoagulation) presented with seizurelike activity. His wife found him on the floor with shaking of his right arm and right leg. The shaking occurred intermittently and lasted for seconds to minutes without loss of consciousness. He subsequently became more lethargic and was taken to the hospital approximately 10 hours after symptom onset. His vital signs, including oxygen saturation and blood pressure, were normal. His tone was increased in all 4 extremities, worse on the right. He was able to move his left arm and leg against gravity. His right arm was forcibly flexed at the elbow and his right leg was fixed in an extended position; neither could be moved by passive range of motion. He had no facial numbness or weakness. The patient had no speech output but was able to nod yes and no appropriately to some questions. He was hyperreflexic in his knees and ankles with upgoing toes bilaterally.

\section{Questions for Consideration:}

1. Given his presentation and examination, how would you localize these symptoms to shape a differential diagnosis?

2. What additional history would help narrow the differential?

\section{GO TO SECTION 2}




\section{Section 2}

To help narrow the differential diagnosis, localization is key. The increased tone, hyperreflexia, and Babinski signs are upper motor neuron signs suggestive of a central etiology. The patient had some involvement of all 4 extremities, although the right side was more severely affected. With bilateral symptoms and lack of facial involvement, this raises suspicion for cervical cord pathology. However, the patient's decreased level of consciousness indicates that the symptoms more likely localize to the brain. The features of decreased consciousness and lack of speech production suggest a cortical process as opposed to a subcortical process.

Given this pattern of localization, the differential is broad and includes vascular events such as ischemic and hemorrhagic stroke, infectious processes such as herpes simplex virus encephalitis, inflammatory processes such as autoimmune encephalitis, toxic events such as drug overdose or withdrawal, metabolic events such as hypoglycemia or hyponatremia, traumatic events such as a fall resulting in a subdural hemorrhage, and neoplastic events such as a brain tumor or leptomeningeal spread.

The history was negative for trauma or cancer. Initial laboratory values including glucose, sodium, and urine drug screen were negative for abnormalities. The patient had no history of seizures in himself or his family. The patient's wife denied fever, behavioral changes, or noticeable confusion prior to the onset of the patient's symptoms that would have suggested encephalitis. The acuity of the symptoms suggests a diagnosis such as seizure or stroke.

\section{Questions for Consideration:}

1. Are there any acute treatment considerations?

2. What tests would you order to determine the cause of the patient's symptoms? 


\section{Section 3}

The patient arrived to the emergency department 10 hours after symptom onset. If the patient had arrived within 4.5 hours, then one important acute treatment consideration after ruling out hemorrhage would have been administration of tissue plasminogen activator given the possibility of a stroke. Due to the concern that these symptoms could represent ongoing seizure activity, the patient was given lorazepam, without improvement in tone or neurologic examination. The patient urgently underwent a CT angiogram of the head and neck, which showed a dominant left anterior cerebral artery (ACA), severe narrowing of the right $\mathrm{A} 3$, and a subocclusive clot in the pericallosal ACA, with patent extracranial vasculature (figure, A). The patient was placed on continuous EEG, which demonstrated diffuse slowing without any evidence of epileptiform discharges in spite of continued symptoms. MRI of the brain demonstrated acute bilateral ACA territory infarcts with small areas of hemorrhagic conversion (figure, B).

A transthoracic echocardiogram demonstrated an ejection fraction of $68 \%$ without valvular abnormality or intracardiac shunt. A 30-day event monitor showed no evidence of atrial fibrillation. The patient's history of DVT was provoked without an underlying clotting disorder that would necessitate restarting anticoagulation. His long-term treatment plan included a highintensity statin and an antiplatelet agent to reduce his risk of subsequent strokes. Given the dominant left ACA, it was hypothesized that he may have had a more proximal clot resulting in the bilateral infarcts that then traveled more distally resulting in the subocclusive clot seen on imaging. The patient was started on tizanidine to improve his tone and discharged to an acute rehabilitation facility with residual right-sided weakness.

\section{Discussion}

The incidence of ACA strokes is $0.6 \%-3 \%{ }^{1,2}$ The most frequently identified etiology of ACA infarctions is cardioembolism (45\%) followed by atherothrombosis (29\%) and small vessel disease (12\%). ${ }^{1}$ The mortality rate of ACA strokes $(7.8 \%)$ is much lower than the mortality of middle cerebral artery (MCA) infarctions (17.3\%). ${ }^{1}$ The typical presentation of acute ACA infarction includes hemiparesis and hemisensory loss of the leg more so than the arm. Less common manifestations of acute ACA strokes include apathy, mutism, and euphoria. ${ }^{2,3}$ Our patient presented with what was thought to be lethargy, but there was likely also a component

Figure CT Angiogram, MRI, and Schematic Representations of the Anterior Cerebral Artery (ACA) Vasculature
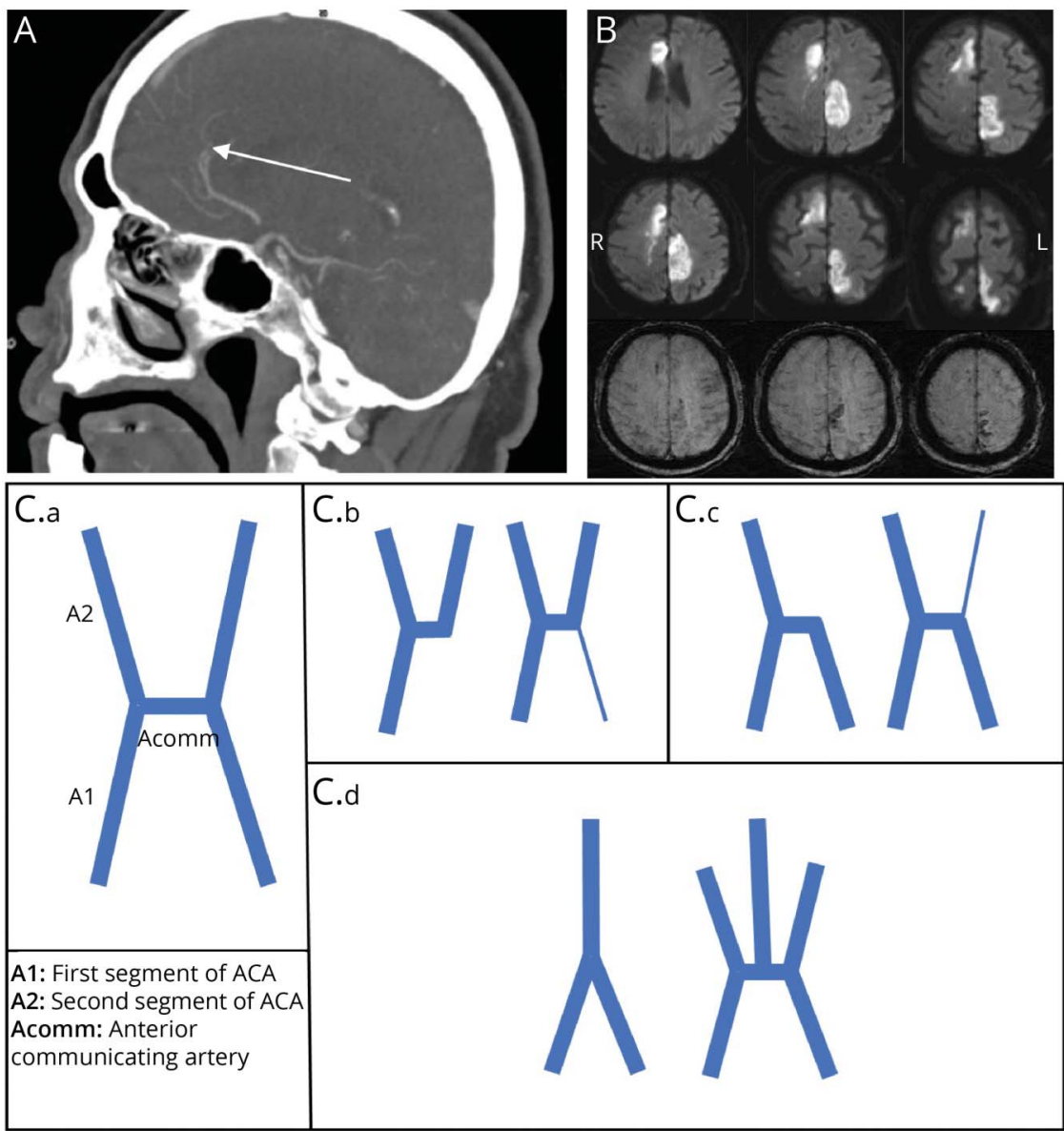

(A) Sagittal view of CT angiogram of the intracranial vasculature demonstrates severe narrowing of the right $A 3$ segment, with a possible subocclusive clot (arrow) in the pericallosal artery portion. (B) Diffusion-weighted axial MRI demonstrates bilateral ACA territory strokes on 6 continuous sequences (top 2 rows) and susceptibilityweighted axial MRI demonstrates areas of hemorrhagic transformation in the areas of the acute ACA infarctions (bottom row). (C) Schematic representations of the ACA vasculature: (a) normal ACA anatomy; (b) absent (left) and hypoplastic (right) A1 segments; (c) absent (left) and hypoplastic (right) A2 segments; and (d) other variants including azygous ACA (left) where the A1 segments come together to form a single A2 trunk and triple ACA (right) where an extra vessel branches off the anterior communicating artery. 
of akinetic mutism given his slow movements and impaired speech production. The atypical features of this patient's acute ACA stroke presentation include anomalous vasculature leading to bilateral infarctions, increased tone as an acute presenting feature, limb-shaking TIA features, and seizure mimicry.

Strokes in the bilateral ACA distribution may have additional symptoms including decreased level of consciousness, parkinsonism, tremor, facial dystonia, and primitive reflexes such as grasp and snout reflex. ${ }^{2}$ High variability in ACA circulation leads to atypical acute stroke presentations, including bilateral strokes. Normal ACA vasculature includes a left and right A1 and A2 segment connected by the anterior communicating artery (figure, C.a). Variants include absent or hypoplastic A1 or A2 segments (figure, C.b and C.c) as well as the rare azygous ACA, which consists of a common trunk in the A2 segment (figure, C.d). The azygous variant carries a significantly increased risk of bilateral ACA infarction, although its prevalence is less than $2 \%{ }^{4}$ Our patient had left dominant ACA vasculature, meaning that his bilateral ACA circulation was supplied from a single Al segment (figure, C.b). This variation may help explain why our patient developed bilateral ACA territory strokes if he initially had a more proximal occlusion that then traveled more distally to the right A3 segment.

Our patient's increased tone resembled spasticity on initial neurologic examination. ACA strokes presenting with significantly increased tone is a symptom that has been reported previously., 5 Spasticity and hyperreflexia typically develop weeks after an ischemic lesion, and it would be unusual to occur within hours of symptom onset. An alternative explanation for the increased tone could be lead pipe rigidity secondary to parkinsonism from the bilateral ACA strokes. One mechanism for the development of increased tone is damage to the descending motor pathways and dorsal reticulospinal tract, which are the main inhibitory tract for spinal reflex activity. ${ }^{5}$ Another mechanism may be interruption of cortical inhibitory projections of the motor control centers emanating from the anterior cingulate region. ${ }^{5}$

Limb-shaking presenting as a TIA is a rare phenomenon that has previously been reported. ${ }^{7,8}$ Limb-shaking TIAs are typically associated with severe carotid stenosis, last less than 5 minutes, and are often accompanied by paresis of the affected limb. ${ }^{7}$ Characteristics distinguishing limb-shaking TIAs from focal motor seizures include retention of consciousness, lack of Jacksonian march, sparing of the face and trunk, no epileptiform discharges on EEG, and episodes triggered by maneuvers that compromise cerebral perfusion such as standing up. ${ }^{1}$ Although the majority of limb-shaking TIAs are secondary to severe carotid stenosis, they may also be secondary to severe intracranial stenosis, including ACA stenosis in patients with patent carotids. ${ }^{8,9}$ The mechanism driving limbshaking TIAs involves impaired cerebral perfusion. This hypothesis is further corroborated by imaging demonstrating a low perfusion hemodynamic state, particularly in the ACAMCA border zone, in patients with limb-shaking TIAs. ${ }^{9}$
The episodic limb shaking and increased tone that this patient presented with is a diagnostic challenge because the symptoms closely mimic a focal motor seizure. It is important to recognize that seizure activity emanating from the mesial frontal lobe, which is a possible epileptic focus given the location of this patient's stroke, may not register on surface EEG due to its deep location. ${ }^{10}$ Although the lack of improvement after lorazepam and absence of epileptiform activity on continuous EEG makes seizure a less likely diagnosis, it cannot definitively be ruled out. Our patient's shaking was likely due to brain tissue hypoxia but it is difficult to definitively determine whether this hypoxia was due to low perfusion in the setting of A3 stenosis or seizure that could not be detected on EEG.

This case highlights several important aspects of atypical acute ACA stroke presentation, including variable ACA vasculature that can lead to bilateral infarctions, increased tone as a presenting feature, limb-shaking ischemic events, and seizure mimicry. It is important to recognize these atypical presentations so that appropriate and timely treatment may be initiated.

\section{Study Funding}

No targeted funding reported.

\section{Disclosure}

The authors report no disclosures relevant to the manuscript. Go to Neurology.org/N for full disclosures.

Appendix Authors

\begin{tabular}{lll}
\hline Name & Location & Contribution \\
\hline $\begin{array}{l}\text { Jessica } \\
\text { Frey, MD }\end{array}$ & $\begin{array}{l}\text { West Virginia } \\
\text { University, } \\
\text { Morgantown }\end{array}$ & $\begin{array}{l}\text { Conceptualization, writing of the } \\
\text { first draft, major revisions }\end{array}$ \\
\hline $\begin{array}{l}\text { Eric } \\
\text { Seachrist, } \\
\text { MD }\end{array}$ & $\begin{array}{l}\text { West Virginia } \\
\text { University, } \\
\text { Morgantown }\end{array}$ & $\begin{array}{l}\text { Conceptualization, major } \\
\text { revisions }\end{array}$ \\
\hline
\end{tabular}

\section{References}

1. Arboix A, Garcia-Eroles L, Sellares N, Raga A, Oliveres M, Massons J. Infarction in the territory of the anterior cerebral artery: clinical study of 51 patients. BMC Neurol. 2009;9:30.

2. Kumar K, Strbian D, Sundaranajan S. Acute cerebral infarctions presenting with weakness in both legs and one arm. Stroke. 2015;46(6):e134-e136.

3. Kumral E, Bayulkem G, Evyapan YN. Spectrum of anterior cerebral artery territory infarction: clinical and MRI findings. Euro J Neurol. 2002;9(6):615-624.

4. Makowicz G, Poniatowska R, Lusawa M. Variants of cerebral arteries: anterior circulation. Pol J Radiol. 2013;78(3):42-47.

5. Alves I, Cruz VT, Grebe HP. Spasticity as the first manifestation of ischemic lesions involving the cingulum. Hindawi Case Rep Neurol Med. 2013:1-3.

6. Bogousslavsky J, Martin R, Moulin T. Homolateral ataxia and crural paresis: a syndrome of anterior cerebral artery territory infarction. J Neurol Neurosurg Psychiatry. 1992;55(12):1146-1149.

7. Persoon S, Kappelle LJ, Klijn CJM. Limb-shaking transient ischaemic attacks in patients with internal carotid artery occlusion: a case-control study. Brain. 2010; 133(part 3):915-922.

8. Ali S, Khan MA, Khealani B. Limb-shaking transient ischemic attacks: case report and review of literature. BMC Neurol. 2006;6:5.

9. Han SW, Kim SH, Kim JK, Park CH, Yun MJ, Heo JH. Hemodynamic changes in limb shaking TIA associated with anterior cerebral artery stenosis. Neurology. 2006;63(8): 1519-1521.

10. Foldvary N, Klem G, Hammel J, Bingaman W, Najm I, Luders H. The localizing value of ictal EEG in focal epilepsy. Neurology. 2001;57(11):2022-2028. 


\section{Neurology}

\section{Clinical Reasoning: A 70-Year-Old Man With Right Arm and Leg Shaking Jessica Frey and Eric Seachrist \\ Neurology 2021;96;1098-1101 Published Online before print April 13, 2021 \\ DOI 10.1212/WNL.0000000000012047}

\section{This information is current as of April 13, 2021}

\section{Updated Information \& Services}

References

Citations

Subspecialty Collections

Permissions \& Licensing

Reprints including high resolution figures, can be found at: http://n.neurology.org/content/96/23/1098.full

This article cites 9 articles, 3 of which you can access for free at: http://n.neurology.org/content/96/23/1098.full\#ref-list-1

This article has been cited by 2 HighWire-hosted articles: http://n.neurology.org/content/96/23/1098.full\#\#otherarticles

This article, along with others on similar topics, appears in the following collection(s):

Clinical neurology examination

http://n.neurology.org/cgi/collection/clinical_neurology_examination Clinical neurology history

http://n.neurology.org/cgi/collection/clinical_neurology_history

Other cerebrovascular disease/ Stroke

http://n.neurology.org/cgi/collection/other_cerebrovascular_disease_st roke

Information about reproducing this article in parts (figures,tables) or in its entirety can be found online at:

http://www.neurology.org/about/about_the_journal\#permissions

Information about ordering reprints can be found online:

http://n.neurology.org/subscribers/advertise

Neurology ${ }^{\circledR}$ is the official journal of the American Academy of Neurology. Published continuously since 1951, it is now a weekly with 48 issues per year. Copyright (? 2021 American Academy of Neurology. All rights reserved. Print ISSN: 0028-3878. Online ISSN: 1526-632X.

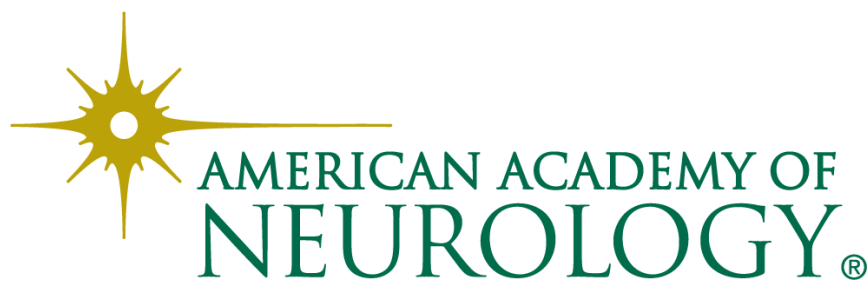

